\title{
Peningkatan Nilai Tambah dan Strategi Pengembangan Usaha Pengolahan Salak Manonjaya
}

\author{
Hepi Hapsari, Endah Djuwendah, Tuti Karyani \\ Jurusan Sosial Ekonomi, Fakultas Pertanian, Universitas Padjadjaran \\ Korespondensi: hapsari.hepi@yahoo.co.id
}

\begin{abstract}
Increasing The added value and The Development Strategy of Processed-salak Manonjaya Enterprise

The processing of salak (Sallaca edulis) - well known as salak Manonjaya - in Tasikmalaya is expected may increases the price of this fruit and the revenue of the producers. The aims of the research were to identify 1) the added value of salak processing, 2) the internal and external factors that influence the salak processing enterprise and 3) the developing strategies of salak processing. The research method was descriptive survey. The respondents were producer and traders of processed salak in Tasikmalaya. The data were analyzed using added value, revenue-cost ratio, and internal-external analysis. The results showed that of production of dodol, sweetpreserved salak, and salak chips increase the added value of $\mathrm{Rp} 6.234,65 / \mathrm{kg}, \mathrm{Rp}$ $10.443,23 / \mathrm{kg}$ and $\mathrm{Rp} 2.297,33 / \mathrm{kg}$ respectively. The internal factors of strength and weakness of the salak processing enterprise as well as the external factor of the opportunity and threat has been documented. The strategy of developing salak processing enterprise in Manonjaya was to hold and maintain market penetration and products diversity.
\end{abstract}

Key words: Salak processing, Added value, Enterprise developing strategies

\begin{abstract}
ABSTRAK
Pengolahan buah salak Manonjaya dapat meningkatkan nilai jual buah dan pandapatan produsen. Penelitian ini bertujuan untuk mengetahui 1) nilai tambah pengolahan salak, 2) faktor internal dan eksternal yang mempengaruhi usaha pengolahan salak, dan 3) strategi pengembangan pengolahan salak. Metode yang digunakan adalah survei deskriptif. Responden penelitian adalah para pengrajin dan pedagang produk olahan salak di Tasikmalaya. Data dianalisis dengan analisis nilai tambah, rasio penerimaan terhadap biaya, dan analisis faktor internal-ektenal. Hasil menelitian menunjukkan bahwa produksi dodol, manisan dan keripik salak menciptakan nilai tambah sebesar masing-masing Rp 6.234,65/kg, Rp 10.443,23/kg dan $\mathrm{Rp} 2.297,33 / \mathrm{kg}$. Faktor internal kekuatan dan kelemahan usaha pengolahan buah salak, dan juga faktor eksternal yang menjadi peluang dan ancamannya telah diinventarisasi. Strategi untuk mengembangkan usaha pengolahan buah salak di Manonjaya adalah mempertahankan dan memelihara penetrasi pasar serta diversifikasi produk olahan.

Kata kunci: Pengolahan salak, Nilai tambah, Faktor internal-eksternal, Strategi pengembangan usaha
\end{abstract}




\section{PENDAHULUAN}

Tasikmalaya merupakan salah satu sentra produksi salak di Jawa Barat. Salak yang dikenal dengan nama Salak Manonjaya dengan rasa rasanya manis sedikit keset, daging buah tebal, dan aroma harum, Salak Manonjaya banyak disukai konsumen daerah di Jawa Barat bahkan luar negeri seperti Belanda, Amerika, dan negara di Eropa.

Saat ini jumlah tanaman salah dan juga produksi Salak Manonjaya cenderung menurun (BPS Kabupaten Tasikmalaya, 2007) karena para petani enggan berusahatani salak. Saat musim biasa, harga di tingkat petani berkisar Rp 800/kg - Rp $1.400 / \mathrm{kg}$ tetapi saat panen raya harga jatuh mencapai Rp 400/kg - Rp 600/kg bahkan akhirakhir ini harga anjlok mencapai Rp200/kg. Setelah krisis ekonomi, harga salak per kg hanya setara 8 $\%-30 \%$ harga beras.

Penurunan harga jual Salak Manonjaya disebabkan oleh berbagai faktor, diantaranya 1) kualitas buah menurun, yaitu menjadi keset dan ukuran mengecil, 2) daya beli masyarakat menurun akibat krisis ekonomi di tahun 1997 lalu, dan 3) kalah bersaing dengan salak dari daerah lain terutama Salak Pondoh dari Sleman Yogyakarta yang rasanya lebih manis.

Di sisi lain salak tergolong komoditas hortikultura yang umumnya bersifat buah musiman. Salah yang berpola respirasi klimaterik mempunyai karakter mudah rusak sehingga umur simpan relatif pendek. Permasalahan yang timbul saat panen raya adalah produksi berlimpah sehingga petani terpaksa menjual dengan harga murah. untuk menghindari kerugian akibat kerusakan (Purnaningsih, 2006).

Keadaan ini semakin membebani para petani salak yang umumnya masih tergolong kelas menengah ke bawah. Untuk menghadapai masalah tersebut masa simpan buah harus diperpanjang sehingga memiliki nilai tambah dan sekaligus meningkatkan nilai ekonomisnya. Salah satu upaya adalah dengan proses pengolahan dan pengawetan salak segar menjadi produk olahan seperti dodol, wajit, manisan, asinan dan keripik salak. Hasil pengolahan salak tersebut dapat memiliki nilai tambah ganda yaitu memperpanjang waktu simpan buah salak dan meningkatkan nilai jualnya (Anarsis, 2003). Namun belum diketahui secara pasti berapa besar nilai tambahnya, faktor-faktor kekuatan,

Tabel 1. Prosedur Perhitungan Nilai Tambah

\begin{tabular}{|c|c|c|}
\hline \multicolumn{3}{|c|}{ Keluaran (output) Masukan (input) dan Harga } \\
\hline 1 & Output/produk total (kg/ proses produksi) & A \\
\hline 2 & Input bahan baku (kg/ proses produksi) & $\mathrm{B}$ \\
\hline 3 & Input tenaga kerja (HOK/proses produksi) & $\mathrm{C}$ \\
\hline 4 & Faktor konversi (kg output / kg bahan baku) & $\mathrm{D}=\mathrm{a} / \mathrm{b}$ \\
\hline 5 & Koefisien tenaga kerja ( HOK/ kg bahan baku) & $\mathrm{E}=\mathrm{c} / \mathrm{b}$ \\
\hline 6 & Harga output (Rp/Kg) & $\mathrm{F}$ \\
\hline 7 & Upah rata-rata tenaga kerja ((Rp/ proses produksi) & $\mathrm{G}$ \\
\hline \multicolumn{3}{|c|}{ Pendapatan dan Keuntungan } \\
\hline 8 & Harga input bahan baku (Rp/Kg) & $\mathrm{H}$ \\
\hline 9 & Sumbangan unput lain (Rp/Kg) & I \\
\hline 10 & Nilai Output $(\mathrm{Rp} / \mathrm{Kg})$ & $\mathrm{J}=\mathrm{d} \times \mathrm{f}$ \\
\hline \multirow[t]{2}{*}{11} & Nilai tambah $(\mathrm{Rp} / \mathrm{Kg})$ & $\mathrm{K}=\mathrm{j}-\mathrm{h}-\mathrm{i}$ \\
\hline & Rasio Nilai tambah (\%) & $1 \%=\mathrm{k} / \mathrm{j} \times 100$ \\
\hline \multirow[t]{2}{*}{12} & Pendapatan tenaga kerja (Rp/Kg) & $M=\mathrm{exg}$ \\
\hline & Bagian tenaga kerja (\%) & $\mathrm{N} \%=\mathrm{m} / \mathrm{kX} 100 \%$ \\
\hline \multirow[t]{2}{*}{13} & Keuntungan (Rp/Kg) & $\mathrm{O}=\mathrm{k}-\mathrm{m}$ \\
\hline & Bagian keuntungan (\%) & $\mathrm{P} \quad \%=\mathrm{o} / \mathrm{j}$ X $100 \%$ \\
\hline \multicolumn{3}{|c|}{ Balas Jasa untuk Faktor Produksi } \\
\hline 14 & Marjin (Rp/Kg) & $Q=j-h$ \\
\hline & a. Pendapatan tenaga kerja (\%) & $\mathrm{R} \%=\mathrm{m} / \mathrm{q} \times 100 \%$ \\
\hline & b.Sumbangan input lain (\%) & $\mathrm{S} \%=\mathrm{i} / 1 \mathrm{X} 100 \%$ \\
\hline & c. Keuntungan (\%) & $\mathrm{T} \%=\mathrm{o} / \mathrm{q} \times 100 \%$ \\
\hline
\end{tabular}

Sumber: Hayami, (1987) 
kelemahan, ancaman dan peluang bagi usaha pengolahan salak, serta strategi pengembangannya. Berdasarkan permasalahan tersebut maka tujuan penelitian ini adalah menganalisis nilai tambah usaha pengolahan salak, mengidentifikasi faktorfaktor yang menjadi kekuatan, kelemahan, peluang dan ancaman usaha, serta menentukan strategi pengembangan usaha pengolahan salak Manonjaya.

\section{METODE PENELITIAN}

Penelitian dilakukan di Usaha Kecil Menengah (UKM) Binangkit Tasikmalayan, pada tahun 2008. Desain penelitian adalah survei deskriptif dengan subyek penelitian adalah pengrajin pengolahan salak dan pedagang produk olahan salak yang terdapat di Kecamatan Manonjaya, Kabupaten Tasikmalaya

\section{Analisis Nilai Tambah}

Analisis nilai tambah ditentukan melalui metode menurut Hayami (1987) dengan prosedur yang terlihat di Tabel 1. Informasi yang dihasilkan melalui metode Hayami pada subsistem pengolahan ini berupa: (a) nilai tambah (Rp), (b) rasio nilai tambah (\%), menunjukan persentase nilai tambah dari nilai produk, (c) balas jasa tenaga kerja (Rp), menunjukkan besarnya upah uang yang diterima oleh tenaga kerja langsung, (d) bagian tenaga kerja $(\%$,$) menunjukkan persentase imbalan tenaga kerja$ dari nilai tambah, (e) keuntungan (Rp), menunjukkan bagian yang diterima pengusaha dan (f) tingkat keuntungan (\%) menunjukkan persentase keuntungan terhadap nilai tambah.

\section{Analisis Pendapatan dan R/C}

Untuk menghitung efisiensi usaha digunakan analisis R/C (Rodjak, 2006) yaitu nisbah antara penerimaan (Revenue, R) dengan biaya total (Cost, C). Dengan dasar pertimbangannya jika $\mathrm{R} / \mathrm{C}>1$ maka usaha menguntungkan, sedangkan jika $\mathrm{R} / \mathrm{C}=1$ maka impas dan jika $\mathrm{R} / \mathrm{C}<1$ berati usaha tidak menguntungkan.

\section{Analisis Strategi}

Analisis strategi untuk pengembangan usaha pengolahan salak diawali dengan analisis SWOT

Tabel 2. Perhitungan nilai tambah pengolahan salak per kg bahan baku untuk setiap proses produksi di UKM Binangkit Tasikmalaya Tahun 2008

\begin{tabular}{|c|c|c|c|c|}
\hline No. & Uraian & Dodol & Manisan & Keripik \\
\hline \multirow[t]{8}{*}{1.} & Output, input dan harga & & & \\
\hline & a. Output/ produk total $(\mathrm{kg} /$ produksi) & 37,50 & 16,00 & 2,00 \\
\hline & b. Input bahan baku (Kg/produksi) & 60,00 & 20,00 & 20,00 \\
\hline & c. Input tenaga kerja (HOK) & 4,00 & 2,00 & 1,50 \\
\hline & d. Faktor konversi & 0,62 & 0,80 & 0,10 \\
\hline & e. Koefisien tenagakerja & 0.067 & 0,100 & 0,050 \\
\hline & f. Harga output $(\mathrm{Rp} / \mathrm{Kg})$ & 20.000 & 20.000 & 65.000 \\
\hline & g. Upah tenaga kerja $(\mathrm{Rp} / \mathrm{HOK})$ & 20.000 & 20.000 & 20.000 \\
\hline \multirow[t]{10}{*}{2.} & Penerimaan dan keuntungan & & & \\
\hline & h. Harga input bahan baku $(\mathrm{Rp} / \mathrm{Kg})$ & $1.000,00$ & $1.000,00$ & $1.000,00$ \\
\hline & i. Sumbangan input lain $(\mathrm{Rp} / \mathrm{Kg})$ & $5.265,35$ & $4.556,77$ & $3.202,67$ \\
\hline & j. Nilai output $(\mathrm{Rp} / \mathrm{Kg}$ & $12.500,00$ & 16.000 & $6.500,00$ \\
\hline & k. Nilai tambah $(\mathrm{Rp} / \mathrm{Kg})$ & $6.234,65$ & $10.443,23$ & $2.297,33$ \\
\hline & 1. Rasio nilai tambah (\%) & 49,88 & 65,27 & 35,34 \\
\hline & m. Pendapatan tenaga kerja $(\mathrm{Rp} / \mathrm{Kg})$ & $1.340,00$ & $2.000,00$ & 1000,00 \\
\hline & n. Pangsa tenaga kerja (\%) & 21,49 & 19,15 & 71.38 \\
\hline & o. Keuntungan $(\mathrm{Rp} / \mathrm{Kg})$ & $4.894,50$ & $8.443,23$ & $1.297,33$ \\
\hline & p. Tingkat keuntungan (\%) & 41,88 & 52,77 & 19,96 \\
\hline \multirow[t]{5}{*}{3.} & Balas jasa pemilik faktor Produksi & & & \\
\hline & $\operatorname{margin}(\mathrm{Rp} / \mathrm{Kg})$ & 11.500 & 15.000 & 5.500 \\
\hline & q. Pendapatan tenaga kerja (\%) & 11,65 & 13,33 & 18,18 \\
\hline & r. Sumbangan input lain (\%) & 45,79 & 33,07 & 58,23 \\
\hline & s. Keuntungan (\%) & 42,56 & 56,29 & 23,59 \\
\hline
\end{tabular}


(Rangkuti, 2004). Rancangan analisis strategi pengembangan mengikuti langkah yang disusun David (2004) yang terbagi atas 3 tahap yaitu 1) pengumpulan data, 2) pencococokan data dan 3) pengambilan keputusan.

\section{HASIL DAN PEMBAHASAN}

\section{Analisis Nilai Tambah}

Berdasarkan analisis nilai tambah (Tabel 3) diketahui bahwa nilai tambah terbesar diperoleh dari pengolahan manisan salak Rp 10.443,23/ kg dan terendah dari pengolahan keripik salak $\operatorname{Rp} 2$ 297,33/kg bahan baku. Pada usaha pengolahan manisan salak tersebut keuntungan yang diperoleh Rp 8.443,23/kg bahan baku sedangkan keuntungan dari pengolahan keripik salak Rp 1.297,33/kg bahan baku. Hasil analisis ini sejalan dengan peneleitian Hapsari dkk. (2007) tentang peningkatan nilai tambah yang diperoleh pada pengolahan daun nilam

\section{Analisis Strategi}

\section{Kekuatan dan Kelemahan Lingkungan Internal}

Lingkungan internal terdiri dari struktur organisasi, suasana kerja, sumberdaya finansial, produk yang dihasilkan, proses produksi, dan lokasi perusahaan. UKM Binangkit Tasik memiliki struktur organisasi yang sederhana (Gambar 1), sehingga memudahkan koordinasi dan pengawasan semua kegiatan usaha.

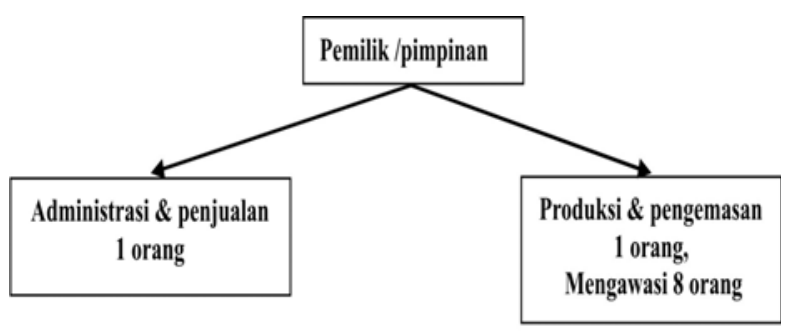

Gambar 1. Struktur Organisasi UKM Binangkit, Tasikmalaya.

Tabel 3. Penerimaan biaya dari setiap kali produksi dan $\mathrm{R} / \mathrm{C}$ usaha pengolahan salak di UKM Binangkit tahun 2008

\begin{tabular}{llllll}
\hline \multicolumn{1}{c}{ Jenis Produk } & $\begin{array}{c}\text { Produksi } \\
(\mathrm{Kg})\end{array}$ & $\begin{array}{c}\text { Penerimaan } \\
(\mathrm{Rp})\end{array}$ & $\begin{array}{c}\text { Biaya produksi } \\
(\mathrm{Rp})\end{array}$ & $\begin{array}{c}\text { Pendapatan } \\
(\mathrm{Rp})\end{array}$ & $\mathrm{R} / \mathrm{C}$ \\
\hline Dodol Salak & 37,5 & 750.000 & $423.420,84$ & $326.579,16$ & 1,77 \\
\hline Manisan Salak & 16,0 & 320.000 & $151.135,42$ & $168.864,58$ & 2,12 \\
\hline eripik salak & 2,0 & 130.000 & $104.053,32$ & $25.946,68$ & 1,25 \\
\hline
\end{tabular}

\section{Analisis Pendapatan Usaha}

Pendapatan tertinggi diperoleh dari dodol salak yaitu $\mathrm{Rp} 326.579,16$ per proses produksi, karena produksi dodol paling banyak 37,5 Kg per proses produksi (Tabel 4). Pendapatan terendah adalah dari pemebuatan keripik salak yaitu $\mathrm{Rp} 25.946,68$ per proses produksi, karena produksi keripik salak hanya $2 \mathrm{Kg}$ per proses produksi (Tabel 3).

Secara keseluruhan pengolahan salak merupakan usaha yang layak untuk dilakukan karena semua nilai $\mathrm{R} / \mathrm{C}>1$ (Tabel 3). Nilai R/C tertinggi diberikan oleh pengolahan manisan salak yaitu 2,12 yang artinya setiap Rp 1000,00 biaya yang dikeluarkan akan memberikan pendapatan sebesar Rp 1.120,00 atau keuntungan sebesar Rp 120,00.
Tenaga kerja terdiri atas anggota keluarga dan personal di luar keluarga yang berasal dari sekitar perusahaan. Mereka bertetangga puluhan tahun dan bekerja sejak perusahaan berdiri, sehingga terjalin hubungan baik seperti keluarga, saling percaya, dan merasa memiliki terhadap perusahaan sebagai sumber penghasilan bersama.

Sumber modal UKM Binangkit sebagian merupakan milik pribadi $40 \%$ dan $40 \%$ berupa pinjaman dari berbagai. Modal awal sebesar $\mathrm{Rp} 10$ juta berasal dari BKKBN melalui program kredit Usaha Keluarga Sejahtera (Kukesra). Tahun 2005 UKM mendapat kredit lunak Rp 15 juta, tahun 2005 Rp 15 juta dan terakhir tahun 2008 Rp 40 juta dari BUMN Angkasa Pura II Bandung Jawa Barat. Nilai asset pada akhir tahun 2007 ditaksir mencapai 
Rp 119.000.000. Nilai penjualan per bulan rata-rata mencapai Rp 20.000.000 dan keuntungan rata-rata sekitar Rp 6.000.000 (Profil UKM Binangkit Tasik, 2007).

Produk olahan salak memiliki daya tahan yang relatif lama $4-5$ bulan untuk dodol, 3 bulan untuk manisan dan 2 bulan untuk keripik salak. Keunggulan kripik salak adalah tidak menggunakan zat pengawet, pewarna dan perasa tambahan tetapi berkualitas cukup bagus.

Semua produk "Binangkit Tasik" sudah terdaftar di BPOM dan Deprindag. Kemasan diberi label "Binangkit Tasik", informasi komposisi produk, sertifikasi halal MUI, dan sertifikasi produk IRT. Produsen belum mencantumkan kode produksi, tanggal produksi dan kadaluarsa karena menganggap produk dodol, manisan dan keripik tahan lama dan belum pernah menguji batas kadaluwarsa.

Sejak awal berdiri, perusahaan ini sudah mendapat bantuan peralatan dari Lembaga Ilmu Pengetahuan Indonesia (LIPI) dan Badan Penelitian dan Pengembangan Departemen Pertanian, antara lain satu set mesin pengolahan dodol salak, blender, mixer, 2 set mesin pengoreng hampa udaara (vacum fryng). Peralatan modern membuat perusahaan ini mampu memproduksi olahan salak dalam jumlah dua kali lipat dan beragam. Keripik salak yang renyah dan garing hanya dapat dibuat dengan menggunakan mesin penggorengan hampa udara.

Letak perusahaan cukup strategis yaitu di tepi jalan kecamatan, di belakang kantor pos, dekat pasar dan alun-alun Manonjaya sehingga memudahkan konsumen mencari lokasi perusahaan. Jalan beraspal dan banyak angkutan umum sehingga akses ke perusahaan cukup mudah.

\section{Peluang dan Ancaman Lingkungan Eksternal}

Lingkungan Eksternal meliputi kebijakan pemerintah, kondisi perekonomian global, selera konsumen, pesaing, pemasok dan agen. Dukungan Pemda bagi pengembangan UKM diwujudkan dengan alokasi APBD sebesar 10-12 \%. Beberapa instansi yang berperan membesarkan UKM Binangkit adalah BKKBN, Dinas Pertanian, Perindustrian dan Perdagangan, LIPI, Universitas Pasundan, Litbang Departemen Pertanian, PT Angkasa Pura II. Instansi tersebut beroeran dalam permodalan, peralatan dan teknologi modern, pelatihan dan magang di bidang pemasarn, kewirausahaan, pelatihan teknis dan keterampilan, kemudahan dalam pengajuan persyaratan untuk izin usaha (SIUP), sertifikasi halal MUI dan sertifikasi industri rumah tangga (Binangkit Tasik, 2007)

kenaikan harga minyak mentah dunia mempengaruhi UKM adalah. Dampak dari kenaikan harga minyak mentah adalah kenaikan harga minyak goreng $100 \%$, minyak tanah $100 \%$ dan LPG $60 \%$. Inflasi menurunkan daya beli masyarakat sampai 50 $\%$ karena pendapatan keluarga cenderung tidak meningkat sementara harga kebutuhan pokok naik sampai dua kali lipat.

Minat masyarakat terhadap makanan tradisional semakin baik, terbukti dengan banyaknya pusat penjualan oleh-oleh khas daerah. Pengetahuan masyarakat akan makanan bergizi dan alamiah juga semakin baik. Budaya kembali ke kampung halaman dan membawa oleh-oleh menjadi peluang yang dapat dimanfaatkan oleh para pengrajin makanan tradisional.

Pesaing dan produk substitusi merupakan ancaman bagi usaha olahan salak. Produk subsitusi adalah Dodol Garut, Manisan Cianjur, aneka keripik buah. Oleh karena itu perusahaan terus berupaya meningkatkan pangsa pasar olahan salak sekaligus menambah variasi produk seperi keripik pisang moli, keripik nangka, dan manisan pala.

Hasil pengolahan salak di UKM Binangkit dipasarkan langsung ke konsumen atau melalui agen baik lokal maupu di luar kota (Gambar 2). Hubungan dengan pemasok dan penyalur (agen) bisa menjadi ancaman atau sebaliknya menjadi peluang. Hubungan baik dengan pemasok bahan baku (buah salak) dan bahan penunjang dapat menjamin kesinambungan proses produksi. UKM ini berusaha

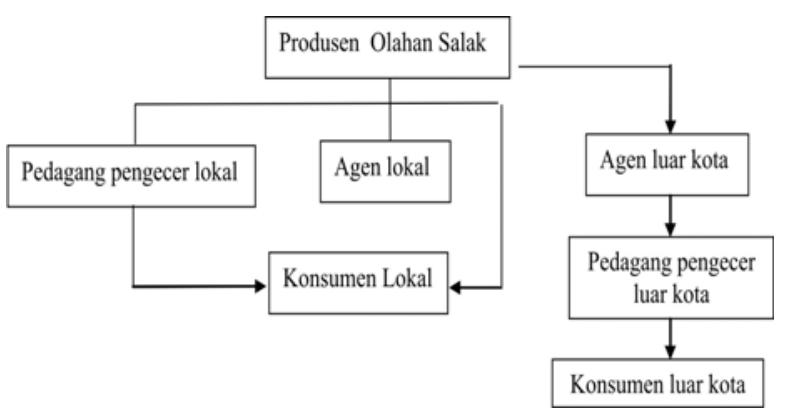

Gambar 2. Saluran Pemasaran salak olahan di UKM Binangkit Tasik

memberi harga pantas, tidak terlalu rendah meskipun saat panen raya sehingga para pemasok bersikap loyal kepada perusahaan. Penjualan kepada pengecer, agen, toko, rumah makan adalah dengan sistem konsinyasi, barang yang tidak laku 
dikembalikan kepada produsen. Selain itu, harga yang mereka tawarkan cenderung rendah dan kurang menguntungkan produsen. Hal ini menjadi ancaman karena risiko ditanggung oleh produsen dan sistem pembayaran giro mundur menyebabkan aliran keuangan terhambat.

Matrik Faktor Internal dan Eksternal Perusahaan Nilai total faktor internal dan eksternal usaha pengolahan salak di UKM Binangkit pada tahun 2008 adalah masing-masing 2,742 dan 2,880 (Tabel 4 dan 5).

Berdasarkan analisis matrik internal eksteral, maka usaha pengolahan salak yang

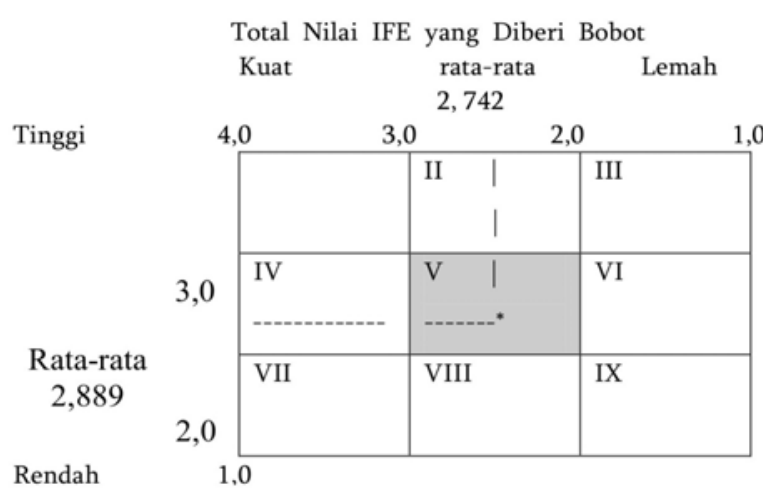

Gambar 3. Matrik Internal-Eksternal usaha pengolahan salak di UKIM Binangkit

Tabel 5. Matrik evaluasi faktor eksternal usaha pengolahan salak UKM Binangkit Tahun 2008

\begin{tabular}{llccc}
\hline No & \multicolumn{1}{c}{ Faktor Eksternal } & Bobot & \multicolumn{2}{c}{ Total nilai } \\
\cline { 3 - 5 } & & & Nilai & Total \\
\hline & A. Peluang (Opportunity) & & & \\
\hline 1. & Dukungan Kebijakan Pemda & 0,123 & 4 & 0,492 \\
2. & Minat masyarakat thd produk olahan meningkat & 0,114 & 3 & 0,342 \\
3. & Budaya membeli oleh-oleh & 0,100 & 3 & 0,300 \\
4. & Hubungan yang baik dengan pemasok & 0,105 & 3 & 0,315 \\
5. & Pertumbuhan RM, toko,pariwisata & 0,073 & 3 & 0,219 \\
6. & Dukungan alat dan teknis dari Litbang, PT, LIPI & 0,096 & 3 & 0,288 \\
\hline & Sub Total & 1.000 & & 1,956 \\
\hline & B. Ancaman (Threats) & & & \\
\hline 1 & Kenaikan biaya produksi & 0.087 & 2 & 0,174 \\
2 & Pesaing produk sejenis dan konstitusi & 0.109 & 3 & 0,327 \\
3 & Agen yang tidak komit & 0,059 & 2 & 0,118 \\
4 & Adanya pengaruh buah musiman & 0,050 & 3 & 0,150 \\
5 & Daya beli masyarakat menurun & 0,082 & 2 & 0,164 \\
\hline & Sub Total & 1,000 & & 0.933 \\
\hline & Total & & & 2,889 \\
\hline
\end{tabular}

dilakukan oleh UKM Binangkit Tasik berada pada posisi sel V (Gambar 3). Pada kondisi tersebut strategi utama perusahaan adalah mempertahankan (hold) dan memelihara (maintain) pasar.

Alternatif strategi pemasaran yang umumnya diterapkan adalah penetrasi pasar dan pengembangan produk Penetrasi pasar berupa mencari pasar yang lebih besar untuk produk atau jasa yang sudah ada melalui pemasaran yang gencar. Pengembangan produk lebih berupaya meningkatkan penjualan dengan memperbaiki produk atau jasa yang sudah ada dan mengembangkan produk atau jasa yang baru (David, 2004).

\section{Alternatif Strategi Pengembagan Usaha Pengolahan Salak}

Berdasarkan analisis Internal Eksternal, strategi pengembangan usaha yang sebaiknya diterapkan oleh UKM Binangkit Tasik adalah:

\section{Strategi Penetrasi pasar (Market Penetration} Strategy)

a. Peningkatan promosi penjualan yang bertujuan untuk menarik pelanggan baru sekaligus mempertahankan pelanggan lama (nilai daya tarik 4,683)

b. Memperluas daerah pemasaran (nilai daya tarik 4,455) 
c. Memasang iklan komersial guna melekatkan image produk dalam benak konsumen.

2. Strategi Pegembangan Produk (Product development strategy)

a. Peningkatan kualitas produk dari aspek bentuk, rasa dan kemasan diantaranya dengan membakukan standar operasional prosedur perusahaan guna menjaga keseragaman hasil produksi, perbaikan desain kemasan dengan alumunium foil dan melengkapi informasi pada label dengan tanggal produksi dan kadaluarsa.

b. Menambah varian produk yang bertujuan untuk menjangkau segmen pasar yang belum tersentuh, diantaranya wajit salak, minuman (sirop) dan asinan salak.

\section{SIMPULAN DAN SARAN}

1. Pengolahan salak dapat memberi nilai tambah berupa keuntungan bagi pengrajin, balas jasa bagi faktor-faktor produksi, dan pendapatan bagi tenaga kerja. Nilai tambah terbesar diperoleh dari pengolahan manisan salak yakni Rp. 10 $443,23 / \mathrm{Kg}$. Pendapatan tertinggi diperoleh dari pengolahan dodol salak yaitu Rp. 326 579,16 per proses produksi. Usaha pengolahan salak memliki $\mathrm{R} / \mathrm{C}>1$ yang artinya layak untuk dilakukan.

2. Faktor internal yang menjadi kekuatan utama usaha pengolahan salak adalah produk khas berkualitas dan proses pengolahan mudah. Sedangkan kelemahan utama adalah belum ada standar produk yang baku. Faktor eksternal yang menjadi peluang utama adalah dukungan Pemda dan berbagai instansi terkait. Sedangkan ancaman utama adalah kenaikan biaya produksi akibat krisis ekonomi.

3. Strategi pengembangan usaha yang direkomendasikan adalah mempertahankan dan memelihara dengan cara penetrasi pasar dan pengembangan produk.

Untuk mengembangkan produk disarankan menambah variasi produk seperti asinan, wajit dan sirup salak sedangkan untuk mengatasi kelemahan dan ancaman usaha dapat dilakukan dengan konsultasi intensif dengan Pemda, instansi terkait atau sesama pengusaha.

\section{UCAPAN TERIMAKASIH}

Terimakasih kepada Lembaga Penlitian, Universitas Padjadjaran yang telah membiayai penelitian ini melalui Dana DIPA PNBP Universitas Padjadjaran, Tahun Anggaran 2008 dengan SPK No. 396/H6.26/LP/PL/2008, tanggal 16 April 2008.

\section{DAFTAR PUSTAKA}

Anarsis, W. 2003. Analisis fungsi produksi agribisnis salak dan industri pangan olahannya. J. Pengkajian Pengem. Teknol. Pert. 6:66-74.

Binangkit Tasik. 2007. Profil UKM Binangkit Tasik. Manonjaya, Tasikmalaya.

Biro Pusat Statistik. 2007. Kabupaten Tasikmalaya dalam Angka 2007. Biro Pusat Statistik. Tasilmalaya.

David, RF. 2004. Manajemen Startegis, Konsepkonsep. Versi Bahasa Indonesia. PT. Prenhallindo. Jakarta.

Hapsari, E. , E. Djuwendah dan T. Karyani. 2007. Ananisis Finansial dan Nilai Tambah Agribisnis Nilam. Laporan Penelitian. Lembaga Penelitian, Unpad. Bandung.

Hayami Y. 1987. Agricultural Marketing and Processing in Upland Java, a Perspective From Sunda Village. CGPRT Center. Bogor.

Purnaningsih, P. 2006. Adopsi Inovasi Pola Kemitraan Agribisnis Hotikultura di Jawa Barat. Disertasi. Sekolah Pasca Sarjana. Bogor.

Rangkuti, F. 2004. Analisis SWOT, Teknis Membedah Kasus Bisnis. PT. Gramedia. Jakarta

Rodjak, A. 2006. Manajemen Usahatani. Pustaka Giratuna. Bandung. 


\section{Indeks}

Agens hayati, 206

Akar wangi, 209

Aktivitas residu, 193

Asosiasi petani, 214

Bakteri endofitik penambat $\mathrm{N}_{2}, 173$

Barringtonia asiatica, 193

Bemisia tabaci, 168

Coleoptera, 167

Capsicum annuum, 200

Crocidolomia pavonana, 193

Curinus coeruleus, 168

Daerah Aliran Sungai, 180

Ekonomi wilayah, 186

Ekstrak biji, 193

Eksudat akar, 208

Faktor internal-eksternal, 216

Foliar treatment, 174

Fosfor tanah 2

Fosfatase, 162

Fungi mikoriza arbuskula, 206

Homoptera, 167

Insektisida, 193

Jagung, 161

Kebijakan pertanian, 186

Kedelai, 161

Kemampuan memangsa, 168

Kepadatan populasi, 200

Keperidian, 168
Kerusakan daun, 200

Konservasi tanah, 180

Kontribusi pendapatan, 209

Lama hidup, 168

Lepidoptera, 192

Location Qoutient, 186

Minyak atsiri, 214

Mortalitas larva, 194

Myzus persicae, 200

Nematoda sista kentang, 206

Nilai tambah, 216

Padi, 173

Penghambatan makan, 194

Pengolahan salak, 216

Peta satuan lahan, 181

Pola pendapatan petani, 209

Pupuk hayati, 162, 173

Rehabilitasi lahan, 180

Sallaca edulis, 216

Sedimentasi, 182

Seed treatment, 174

Sektor basis, 186

Spora fungi mikoriza arbuskula, 207

Strategi pengembangan usaha, 216

Tingkat bahaya erosi, 180

Tectona grandis, 161

Tumpang sari, 162

Universal Soil Loss Equation, 189 